\title{
Legal Importance of Money Creation
}

\author{
Lauris Bočs \\ Rīga Stradiñš University, \\ Doctoral Studies Programme "Law", Latvia
}

\begin{abstract}
Modern economics is based on at least two premises - ease of transactions for goods and services and stable money system as a reliable exchange medium. The latter applies to the science of law directly because legal regulation establishes the particular forms of money being used.

The aim of the research is to analyse legal aspects of systemic money creation. By using descriptive, analytical, systemic and legal-technical methodology, the article examines the role of credit institutions and determines their systemic importance for money creation. The author concludes that credit is the basis for modern money creation which has a deteriorating effect on long term money system stability because of inherent inflation needs.

The author suggests to advance the right of the sovereign to create money, that is, seigniorage in the European Union by establishing criteria within the legal regulation for primary money of the sovereign and secondary money as a derivative asset within the financial sector, which could help to create the future legal adjustments for a sound money system in the European Union with a stable monetary union.

Journal of Economic Literature codes for the article: E51 - Money Supply, Credit, Money Multiplier; K23 - Regulated Industries and Administrative Law.
\end{abstract}

Keywords: European Union, money, inflation, seigniorage.

\section{Introduction}

Money is essentially a measurement tool for the exchange of goods and services $[4,243]$, yet historically political economy distinguishes the gradual deterioration of that tool as a somewhat beneficial occurrence [2, 11]. However, the author cannot distinguish any benefits and also has yet to find analysis about the legal and democratic need for inflation. Since legal interests of people need to be respected in monetary 
policy as well, the author challenges the dogmatic political belief that money should be pre-determined to lose purchasing power in need for economic growth. The author has not found any published juristic analysis about the topic of money creation, yet points out that money is simply a transaction tool established by a legal act which by itself is a result of political and legal discourse. Therefore, sound money systems are directly linked to sound juristic evaluations of legal acts affecting money creation and therefore need to be fundamentally studied within the science of law. The author notes that the published article will be available as a recorded audio article for listening with a creative commons license for both.

The aim of the article is to analyse the concept of money creation according to the fundamental legal doctrine of just legal regulation regarding the modern inflationary nature of money supply which impacts price inflation and higher costs of living for society. The research area is the EU public law, the subject of the article is monetary policy.

The used methods are: descriptive - for the textual description of the conditions, analytical - for the evaluation of research content according to applicability, systemic for the representation of inherent systemic legal conditions and legal-technical - for the reasoning of juristic justifications.

\section{Results}

Money is not a universally given medium, nor a social relationship principle $[5,118]$. The concept of money is fully human made and an issue controlled within the science of law. Equally upon the social science realm is the concept of money systems, which historically have been affected by government policies $[3,200]$. Since this involves more than just social relations, also actual social engineering, the right to actually affect the money supply and its allocation is one of the most crucial legal instruments that exists in our modern civilisation. Such a right inherently belongs to the sovereign of a state and is known as the so-called seigniorage which is the ability to create legal tender by enforcement of legal order $[1,369]$. Therefore, the ability to influence money and its amount in circulation is of vital legal importance to economy because of the nature of money as a valuable item; therefore, the juristic requisites have to be sophisticated.

Contrary to a popular belief, our modern day money supply is not based on gold reserves or any other tangible assets; actually on debt which can be considered as liabilities of credit created ex nihilo, that is, out of nothing [8, 125]. Government spending is not solely dependent on the collected taxes, but rather on liabilities in which the government is involved. Since that means more than just a mere credit transaction, the government has to actually issue something of perceived value, which is mostly government obligations $[6,71]$. These promissory notes entitle the buyer to receive not just the face value, but also the interest, allowing profit to be made. Since 
government spending is a political issue, governments are concerned with political issues, such as those made by the so-called Maastricht Criteria, for instance, determining the maximum percent amount a government should be able to borrow.

The mere concept of a market financed government is legally questionable because of the mentioned seigniorage privilege. For the most part, government creates its own legal tender which in effect means that the sovereign has the legal right to create its own money system as a monopoly $[7,44]$. Only when the sovereign decides to hand this privilege to another subject this is not true. But even then the need for outside money is fairly limited, because citizens of the state could be regarded as inner financiers of government expenditures. Since the state does not hand over the rights to decide upon taxes, the government has the legal right to actually make tax policies that in effect create another form of money which can be used to finance government costs. Contrary to some viewpoints, these actions do not limit the freedoms of the population, rather they allow a government to operate in the interests of the general public in case of needed liquidity.

The legal theory has its limitations only in the case when public and private interests are considered interchangeably. Since the need for private profit and resource control is based on legally binding right to property, the obvious conclusion is that the debt of one is the asset of another. Since most public debt is made by borrowing in the so-called financial markets with private participants, the true interest of the financial market is to keep lending as much as possible because the profit motive is what determines the legal operations of any private commercial credit institution. However, the misconception is that private lenders do not influence the decision by public officials. As a matter of fact, they do so, yet the actual degree of influence could vaguely be considered as lobbyism because of the difficulty of determining the exact amount of influence.

\section{Discussion}

As of this moment, it seems that the legal aspects of money creation are not well analysed within the science of law since the dominating part is being studied in economics. The author points out several discussions in economics that have considerable constitutional aspects and which can be transferred mutatis mutandis into the science of law. The author uses diverse brief exemplary sources for establishing a multitude of viewpoints of whom the juristic aspects are added afterwards.

Modern Money (Monetary) Theory regards money as a hierarchical concept, with government or central bank issued currency as the highest of all. Private credit transactions have liabilities attached to them and, therefore, are not money out of nothing, but just leveraged reserve currency [10, 78]. The meaning of this is that private credit transactions do not increase financial assets in economy, therefore not backed, that is, fiat money is only being created from the state and not private credit institutions. 
Monetary Circuit Theory suggests that the origin of the overwhelming majority of money is systemically endogenous, meaning created in the banking system rather than outside central bank. Since credit transactions involve banks extending credit to borrowers, the central bank has no determining factor in actually issuing such loan promises, yet when these loans are being used, they have to be according to the central bank reserve requirements $[8,125]$. Therefore, credit money comes before central bank reserves.

The author considers noteworthy to point out comparably recent works by Richard Werner, economics professor at the University of Southampton, United Kingdom. After evaluating the financial intermediation theory, fractional reserve theory and credit creation theory Werner concludes that banks actually create usable money by means of accounting, without the need to make transactions to borrowers, but only to write their loans as numbers in their account like in accountancy ledger $[9,16]$. This conclusion has significance in relation to the origins of money and the means of the central bank's ability to influence monetary inflation.

Considering the mentioned viewpoints, the author points out the fact that money has no legal definition, at least not in the European Union, the closest being electronic money. Since there is no legal definition, no hierarchical concept can be considered in terms of an existing political economy, which means that money is absolutely everything that can be used as such without distinction of source. The increasing evidence can be seen by modern means of transaction, namely digital. Digital money is not currency, but is denominated in currency and since digital money represents liabilities for one party, they represent assets for another. That makes it impossible to actually separate private commercial interests from a stable money system as non-commercial interests of general public.

The author considers the theoretical viewpoint for money distinction as an actual benefit for legal considerations because it represents the inherent legal nature - either a payment tool directly from the sovereign or a derivative from the financial sector. The author considers this to be a necessary step towards sound money system legal regulation since it implies empirical distinctions for controlling inflationary monetary policy.

\section{Conclusions}

1. Modern money does not represent anything of legal protection such as assigned precious metals or a fixed denomination, but only the trust of society that ought to be legally protected expressis verbis, that is, stated explicitly.

2. Legal regulations have a fundamental obligation to benefit society at large and monetary policy in the European Union does not provide clear evidence of doing so.

3. The European Union and its member states have the right of legally distinguishing money that has been made by the monetary power as the primary source and 
by credit institutions as secondary sources for money, and such separation could lead to suitable legal analysis within political economy for sound money creation.

4. Juristic analysis has the obligation to consider the actual needs for price inflation within an economy and the author suggests to attach currencies to fixed denominations such as time or services received from government institutions which can have the inevitable quality of being a constant measurement in any systemically regulated sphere of the state.

5. The legal importance of money creation is to ease the facilitation of trade and accumulation of wealth, yet inflationary monetary policy does not seem to be in accordance with the democratic needs of society for a stable money system, which leads to the conclusion that juristic rather than economic approaches are needed to achieve monetary stability.

6. Politics can adopt certain measurements for use in legal acts such as meters, time etc., so at least in theory it can adopt a sound money system where the metaphorical principle applies that a meter is a meter without risk of deteriorating by a few percent every fiscal year.

\section{Naudas radīšanas juridiskā nozīme}

\section{Kopsavilkums}

Mūsdienu ekonomika balstās uz vismaz diviem nosacījumiem - preču un pakalpojumu apmain̦as darījumu èrtumu un drošu naudas sistēmu kā apmaiņas vidi. Pēdējais attiecas uz tiesību zinātni tieši, jo normatīvais regulējums nosaka konkrēti izmantojamo naudas formu.

Pētījuma mērḳis ir analizēt sistēmiskas naudas radīšanas juridiskos aspektus. Lietojot aprakstošo, analītisko, sistēmisko un juridiski tehnisko metodi, rakstā ir izpētīta kredītiestāžu loma un noteikta to sistēmiskā nozīme naudas radīšanā. Rakstā secināts, ka kredīti mūsdienās ir naudas radīšanas pamatā un tie nelabvēlīgi ietekmē ilgtermiņa naudas sistēmas stabilitāti tai piemìtošās inflācijas vajadzības dēḷ.

Lietderīgi ir attīstīt suverēna tiesības radīt naudu jeb t. s. seniora tiesības Eiropas Savienībā. To var īstenot, izveidojot kritēriju normatīvajā regulējumā primārai naudai no suverēna un sekundārai naudai kā atvasinātam aktīvam finanšu sektorā. Šādas izmaiṇas varētu palīdzēt izveidot nākotnes juridiskās korekcijas drošai naudas sistēmai Eiropas Savienībā ar stabilu monetāru savienību.

Ekonomiskās literatūras žurnāla (Journal of Economic Literature) kodi rakstam: E51 - naudas apjoms, kredìts, naudas multiplikators; K23 - regulētas nozares un administratīvās tiesības.

Atslēgvārdi: Eiropas Savienība, nauda, inflācija, seniora tiesības. 


\section{References}

1. Bofinger P., Reischle J., Schächter A. Monetary policy: goals, institutions, strategies, and instruments. Oxford: Oxford University Press, 2001.

2. Gordon R. J. Why stopping inflation may be costly: evidence from fourteen historical episodes. In: Inflation: causes and effects. Ed. by Hall R. E. - Chicago: The University of Chicago Press, 1982, Pp. 11-40.

3. Gouge W. M. History of paper money and banking. Philadelphia: Grigg \& Elliott, 1833.

4. Howells P., Bain K. The economics of money, banking and finance: a European text. $4^{\text {th }}$ ed. Essex: Pearson Education Limited, 2008.

5. Karimzadi S. Money and its origins. Abingdon: Routledge, 2013.

6. Kolb R. W. Sovereign debt: from safety to default. Hoboken: John Wiley \& Sons, 2011.

7. Peacock M. Introducing money. Abingdon: Routledge, 2013.

8. Rochon L.-P., Rossi S. Modern theories of money. The nature and role of money in capitalist economies. Gheltenham: Edward Elgar Publishing Limited, 2003.

9. Werner R. Can banks individually create money out of nothing? The theories and the empirical evidence. International Review of Financial Analysis, 2014; 36: 1-19.

10. Wray L. R. Modern money theory: a primer on macroeconomics for sovereign monetary systems. - New York: Palgrave Macmillan, 2012. 